\title{
後部パラペット堤の越波特性と 背後マウンド部の安定性 \\ STABILITY OF ARMOR UNITS ON A HARBOR-SIDE MOUND AGAINST WAVE OVERTOPPING WITH BACKWARD PARAPETS
}

\author{
早川哲也 ${ }^{1} \cdot$ 木村克俊 ${ }^{2} \cdot$ 林忠志 $^{3} \cdot$ 土井善和 ${ }^{4} \cdot$ 渡部靖憲 $^{5}$ \\ Tetsuya HAYAKAWA, Katsutoshi KIMURA, Tadashi HAYASHI, \\ Yoshikazu DOI and Yasunori WATANABE \\ '正会員 北海道開発局 開発土木研究所（广062-0931 札幌市豊平区平岸 1 条 3 丁目） \\ ${ }^{2}$ 正会員 工博 北海道開発局 開発土木研究所 \\ ${ }^{3}$ 工修 北海道開発局 開発土木研究所 \\ ${ }^{4}$ 北日本港湾コンサルタント株式会社 \\ ${ }^{5}$ 正会員 工博 北海道大学大学院助手 工学研究科
}

\begin{abstract}
The high mound is sometimes constructed behind a composite breakwater in order to increase the sliding resistance and utilize the mound for an aquacultural purpose. The high mound must be covered by armor units with adequate weight to prevent from scattering by overtopping waves. However, the shallower is the submerged depth of the mound, the heavier become the armor units.

This study proposed a backward parapet as a countermeasure to reduce weight of armor units. A numerical simulation showed the difference in the velocity field behind the caisson between the backward and forward parapet. With the backward parapet, large-scale eddies were not observed and the velocity on the mound was slower than that of the forward parapet. Furthermore, hydraulic model tests showed that the stable weight was approximately $40 \%$ less than that of the forward parapet.
\end{abstract}

Key Words : Backward parapets, armor units, wave overtopping

\section{1.はじめに}

近年，我が国の沿岸域では自然環境との調和を 目指した港湾施設整備が進められており，この一環 として釧路港において図ー 1 に示すような水産協調 型防波堤の建設が進められている。この構造は, 混 成堤の.背後に浚渫土砂を用いて天端の高いマウンド 部を設け, 藻場の創出を図るというものである. 加 えてこの構造では, 裏込め土圧による滑動抵抗力が 増加するため, 直立部の重量を低减することが可能 となる。

藻類の光合成を促進させるためには, 背後マウ ンド部の天端水深をできるだけ浅くする必要がある ことから, 越波水の打ち込みに対する背後マウンド
の安定性の確保が重要な課題となる.

背後マウンド被覆材として砕石を用いた場合に ついては, 早川ほか 1により安定重量の算定法が提

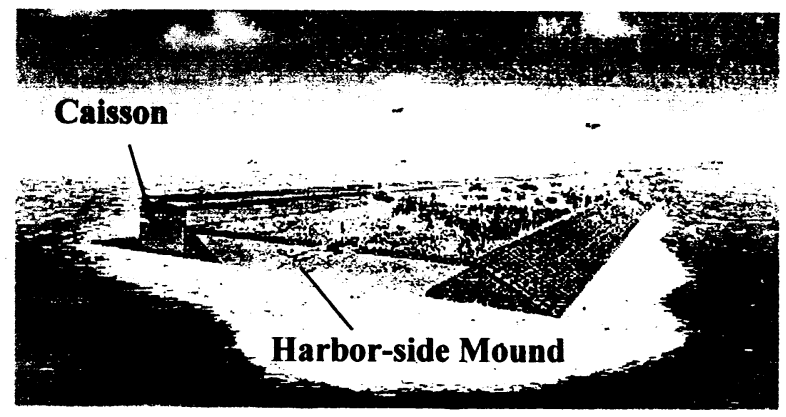

図-1 水産協調型防波堤 
案されている. しかしながら, 背後マウンド天端水 深が浅くなるとともに安定重量が急激に増加するた め, 条件によっては被覆材の施工が経済的に難しく なる場合がある.

そこで本研究では，越波量が減少する「後部パラ ペット堤」 ${ }^{2)}$ 着目し, 数值計算により越波水の打 ち込みによる流体運動を明らかにするとともに，水 理模型実験により背後マウンド被覆材の安定性につ いて検討する。

\section{2. 越波水の打ち込みによる流体運動}

\section{（1）数值計算方法}

越波水の打ち込みに伴う複雑な流体運動を再現 するため, 渡部・佐伯 ${ }^{3)}$ と同様な数值計算を行った。 この手法は, Navier-Stokes 式を支配方程式とし, 自 由水面の決定を密度関数法により行う直接数值計算 であり, 数值拡散を低減させるため移流計算におい て CIP (cubic-polynomial interpolation) 法を適用し ている.

計算領域は図ー2に示すように，堤体前面から造 波境界までの無次元距離 $l_{d} / h$ を 16.84 , 堤体背面か ら透過境界までの無次元距離 $l_{h} / h$ を 6.00 とした. 堤体形状はパラペットが港外側に設置されている通 常堤㧍よび後部パラペット堤の 2 種類とし, 上部工 および港内側マウンドの構造条件は後述する水理模

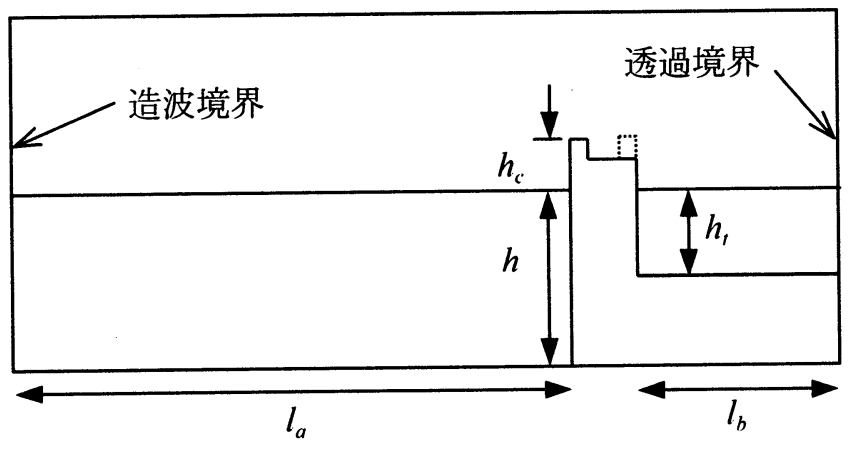

図-2 数値計算領域

型実験に合わせた.

造波境界条件としては楕円関数の母数 $m$ を 0.979 とした 2 次のクノイド波理論を用いた. 波高水深比 $H / h$ が 0.5 , 水深 $h$ を代表長としたレイノルズ数は 1,359,000 であり，これは実験スケールで波高 $H=29 \mathrm{~cm}$ ，周期 $T=2.6 \mathrm{~s}$ の波に相当する.

底面および堤体はノンスリップ条件とし, 格子間 隔 $\Delta x / h=0.03$ および $\Delta y / h=0.03$, タイムステップ $\Delta$ $t / T=1 / 1024$ により計算を行った.

\section{（2）港内側における流速の空間分布}

図一 $3 a, b$ は, 通常堤および後部パラペット堤 における $T / 4$ ごとの流速ベクトルの空間分布であり, 横軸は堤体港内端からの無次元距離 $X / h$ を示してい る. 通常堤（図一3 a ）においては，(1)のように堤

(1) $t / T=0$

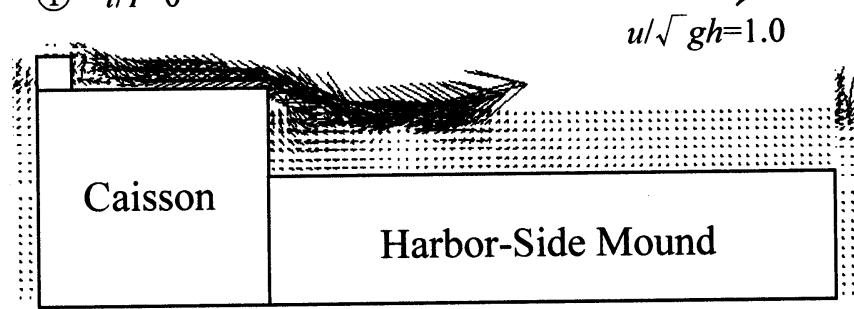

(1) $t / T=0$

(2) $t / T=1 / 4$

(2) $t / T=1 / 4$

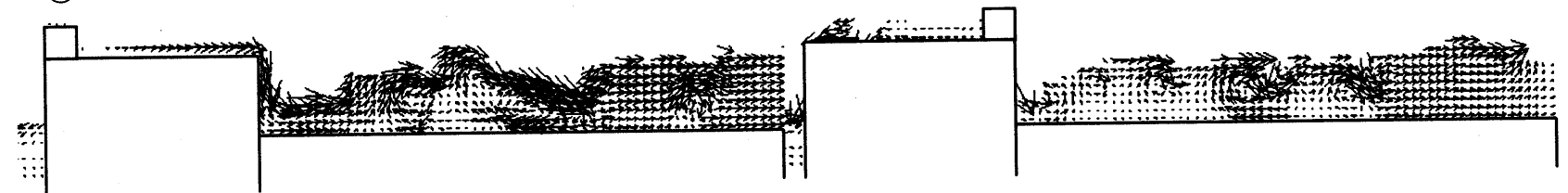

(3) $t / T=1 / 2$

(3) $t / T=1 / 2$

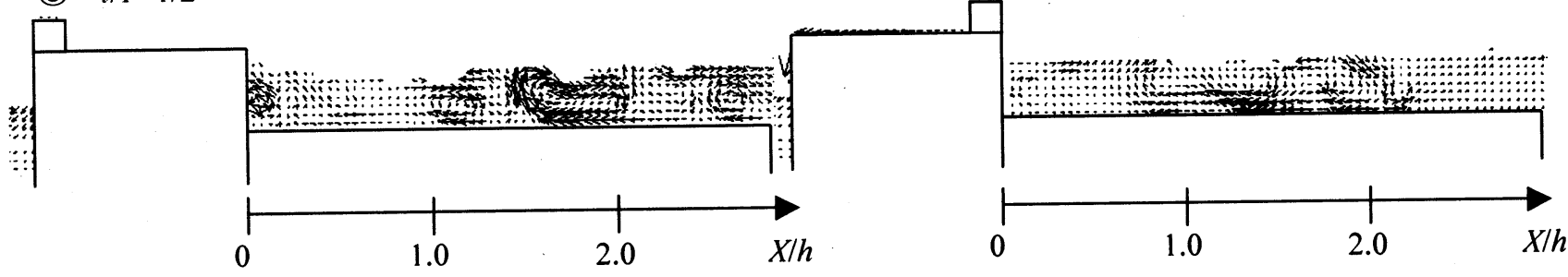




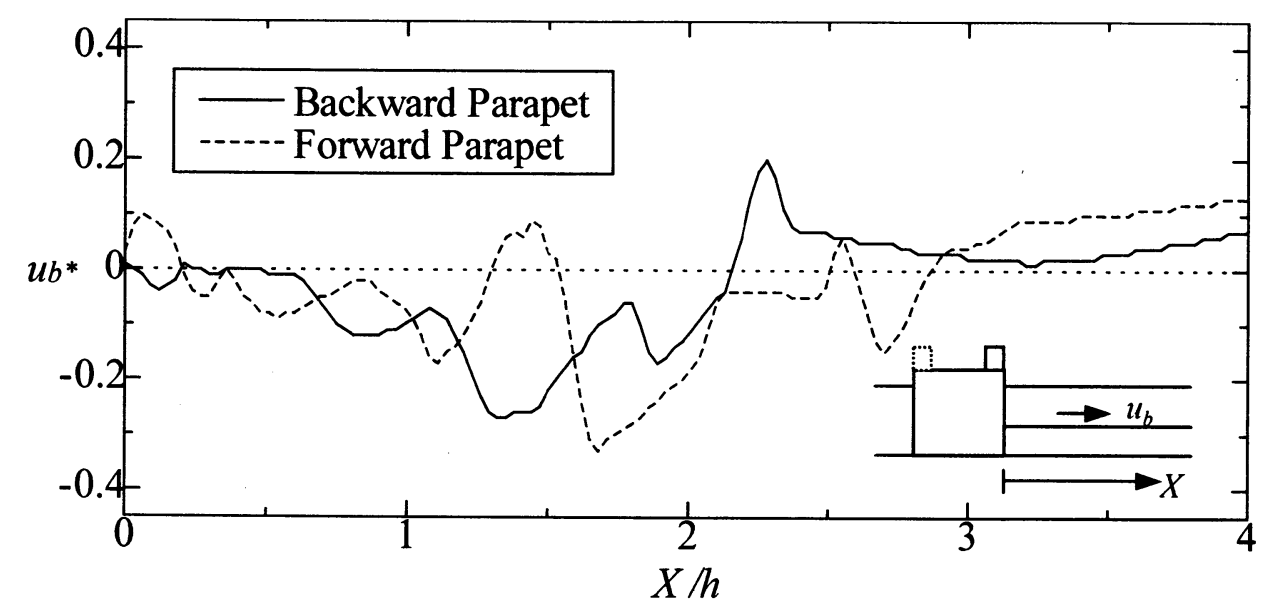

図－4＼cjkstart港内側マウンド天端上流速

体天端上を流れた越波水が $X / h=0.8$ 付近において堤 体背後の水面へ打ち込む. その後, スプラッシュア ップの繰り返しによって(2)のような複数の渦が発生 する.これらの渦は互いに干渉し，(3)ように $X / h=1.8$ において大規模な負の渦が見られ，港内側 マウンド近傍の流速も大きくなっている。また, $X / h=1.2$ および 2.7 付近においても負の渦が見られ, これらの渦の間にはせん断力により誘発された正の 渦も確認できた。

これに対して, 後部パラペット堤（図ー3 b ）の 場合, 越波水がパラペットに衝突し, (1)のように大 きく飛散する.このため, 堤体背後での越波水の流 入箇所が集中せず，(2)のよに水面付近に複数の渦 が発生する.これらの渦は通常堤と比較すると小規 模であり，マウンド天端近傍の流体運動に対する影 響も小さい. また，その後の(3)においても大規模な 渦が見られず, 背後マウンド近傍の流速も通常堤よ り小さくなる.

図ー4は, 背後マウンド近傍での流速が最大とな る時刻（図一 3 の $t / T=1 / 2$ ）における, 堤体からの 無次元距離 $X / h$ と背後マウンド近傍無次元流速 $u_{b^{*}}$ $\left(=u_{b} / \sqrt{g} h\right.$, 正が岸方向の流速）の関係を示したも のである. 通常堤および後部パラペット堤ともに, $X / h=2.0$ 付近までの流速はほぼ負の值で増減を繰り
这している。これは削述した負の渦およびそれに誘 発された正の渦の影響であり，極大・極小值をとる $X / h$ は渦の発生箇所と一致している. また, 後部パ ラペット堤に打ける最大流速は $u_{h^{*}}=-0.27$ $(X / h=1.3)$ であり, 通常堤における $u_{b^{*}}=-0.33$ $(X / h=1.7)$ の $80 \%$ 程度の值を示す. また, 後部パ ラペット堤の $X / h=2.3$ 付近では, 負の流速のピーク 值より小さいものの, 正の流速が卓越しており通常 堤より大きな值を示している.

\section{3. 被覆材の安定性}

\section{（1）実験方法}

水理模型実験は長さ $85 \mathrm{~m}$, 幅 $1.6 \mathrm{~m}$, 高さ $3.0 \mathrm{~m}$ の 二次元造波水路で行っており, 勾配 1/100 のモル夕 ル水路床上に図ー5に示す通常堤および後部パラペ ット堤を設置した. 水深 $h$ は $57.3 \mathrm{~cm}$, 天端高 $h_{c}$ は $17.3 \mathrm{~cm}$, 港内側マウンド天端水深 $h$ ，は $18.3 \mathrm{~cm}$ であ る.

安定実験では, 有義波高 $H_{1 / 3}$ が $29 \mathrm{~cm}$, 有義波周 期 $T_{1 / 3}$ が $2.6 \mathrm{~s}$ の不規則波を 3000 波作用させ, 背後 マウンド被覆材の移動個数を測定した. 被害率は堤 体から岸方向に $120 \mathrm{~cm} （ \fallingdotseq 2 h)$ の範囲での被覆材総

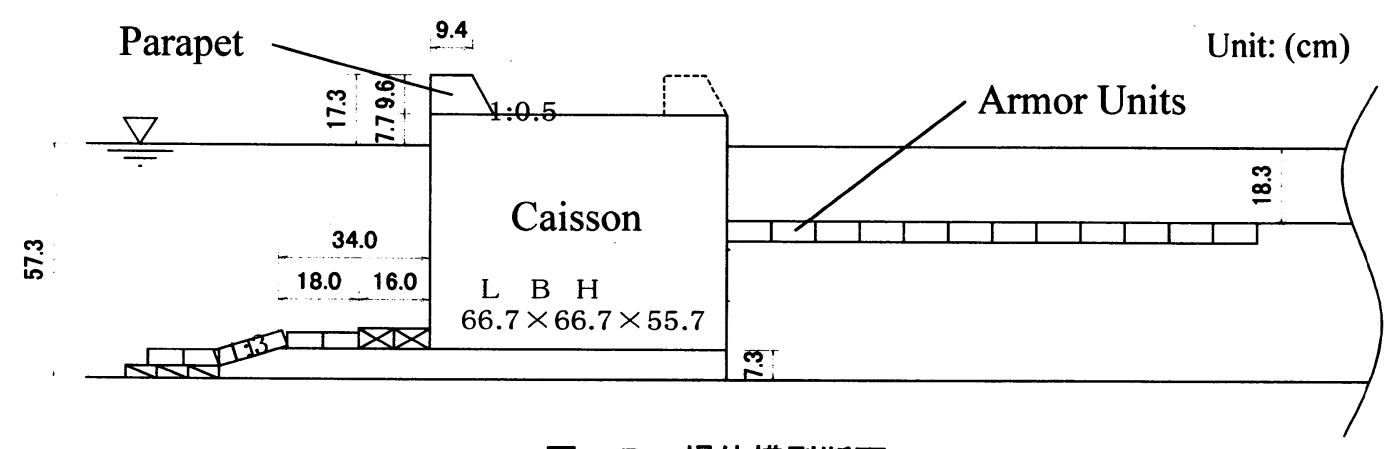

図一 5 堤体模型断面 


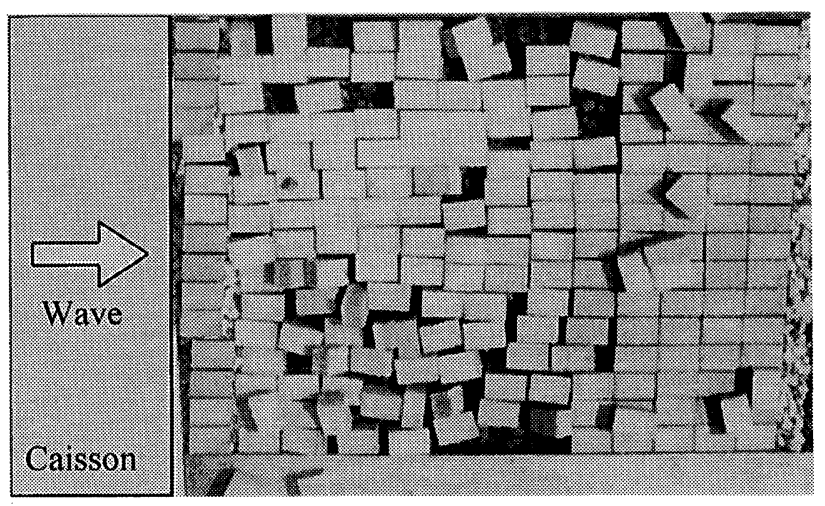

写真一 1 a 被夏材の移動状況（通常堤）

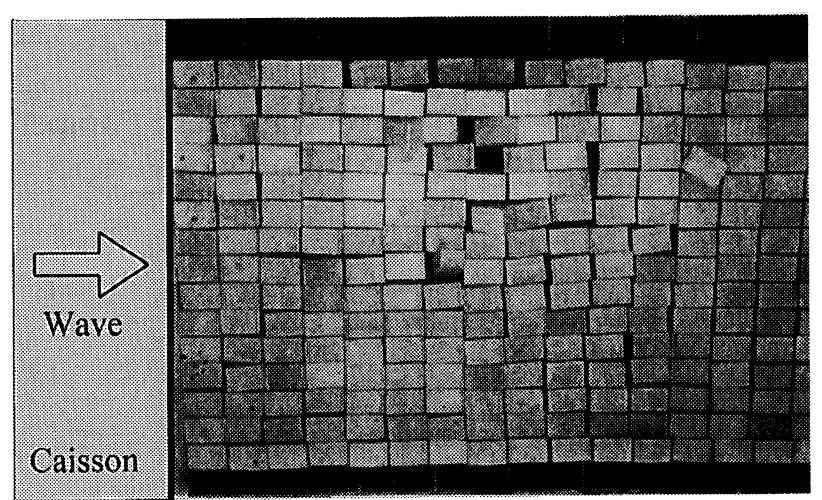

写真一 1 b 被夏材の移動状況（後部パラペット

\section{（3）被夏材の安定重量}

図一 6 は, 被覆材重量 $W$ と被害率 $D$ の関係を示 したものである，W の減少とともに $D$ が急激に増 加する傾向にある. 安定限界 $(D=0 \%)$ となる $W$ に着目すると, 後部パラペット堤では $W=450 \mathrm{gf}$ $(4.4 \mathrm{~N})$ であり, 通常堤 $\left(h_{1}=18.3 \mathrm{~cm}\right)$ の $W=1012 \mathrm{gf}$ （9.9N）の 40\%程度となる. 早川ほか 11 は, 港内側 マウンド被覆材の安定重量が流速の 3 乗に比例する 式を提案しており, 前章で示した後部パラペット堤 におけるマウンド近傍流速の低減率 0.8 を考慮する と, 安定重量は約 $1 / 2$ となり, 実験結果とほぼ一致 する.

\section{4. まとめ}

背後マウンド被覆材の重量を低減する方法の一つ として, 後部パラペット堤を提案し, 数值計算, 水 理模型実験により堤体背後の流体運動および被覆材 の安定重量について検討した. 主要な結果をまとめ ると以下のようになる.

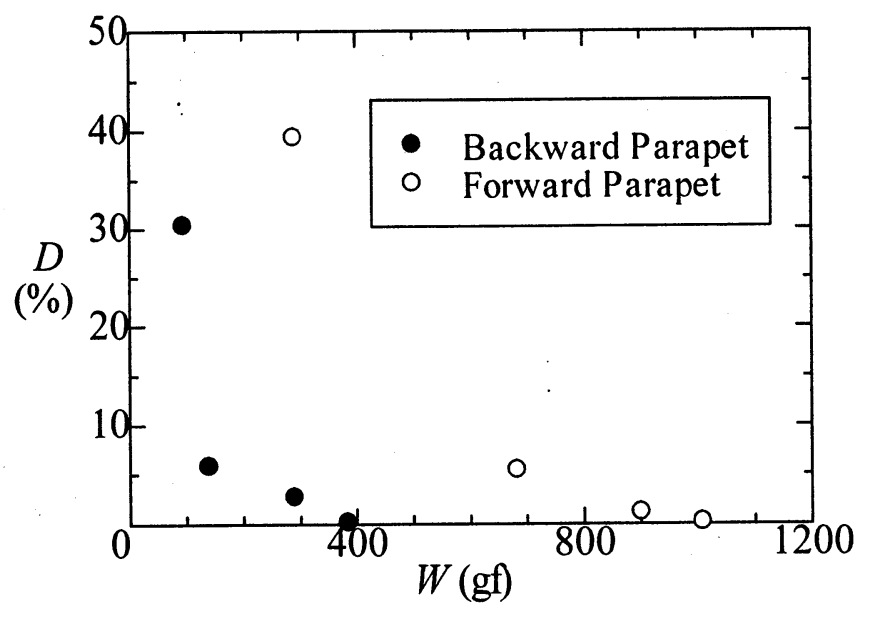

図－6 被㠅材重量と被害率の関係

写真一 2 後部パラペット堤の $D=30 \%$ 状況 
(1)後部パラペット堤の場合, 越波水の飛散が大き いため, 通常堤と比較して大規模な渦の生成が 見られない。

(2)後部パラペット堤では, 堤体方向の流速の最大 值が通常堤の $80 \%$ となる.

(3)通常堤においては，被覆材は越波水の打ち込み により, 堤体方向へ移動するものが多く, 数值 計算により得られた流れの傾向と一致する.

(4)後部パラペット堤においては, ほとんどの被覆 材が岸方向へ移動する。

(5)後部パラペット堤における被覆材の安定限界重 量は，通常堤の $40 \%$ 程度まで減少する.

自然環境との調和を考慮した港湾整備が進められ ている中で, 混成堤の港内側に天端水深の浅いマウ ンドを設ける構造は, 藻類に対する光・流れといっ た環境条件が良好であれば, 藻場創出の有効な手段 であると考えられる．後部パラペット堤は港内側マ
ウンド部の安定性を向上させることができ，積極的 に適用されることが期待される.

今回の検討では, 港内側マウンド部の安定性に対 する後部パラペット堤の有効性を示した. 今後さら に研究を進め, 被覆材の安定重量算定法を提案した い.

\section{参考文献}

1) 早川哲也, 渡部靖憲, 鈴木孝信, 木村克俊, 土井善和, 工藤貴弘：混成堤に打ける越波水の打ち込み特性と被 覆材の安定性, 海岸工学論文集, 第 45 巻, pp. 691-695, 1999.

2) 高田彰, 藤川浩生: パラペット後退型護岸のうちあげ, 越波および波圧の特性, 海岸工学論文集, 第 25 巻, pp. 283-287, 1999.

3) 渡部靖憲, 佐伯浩: 硒波帯内の流速場のダイレクトシ ミュレーション, 海岸工学論文集, 第 43 巻, pp. 71-75, 1996.

(1999. 4. 19 受付) 